\title{
Investigation and Research on the English Learning Status of University Students Based on Computer Network
}

\author{
https://doi.org/10.3991/ijet.v12.i08.7141 \\ Yanli Guo \\ Weifang University of Science and Technology, Weifang, China \\ liouse $5210 @ 163 . \mathrm{com}$
}

\begin{abstract}
This paper analyzes the learning status of public English network course learning of university students, and then builds the "ecological system of public English network course learning" in accordance with the educational ecology theory to sort out various factors influencing the leaning effect and the relations among these factors, finally leading to positive solutions and suggestions.
\end{abstract}

Keywords—computer network, university English, investigation and research, solutions and suggestions

\section{Introduction}

Currently, many universities initialized internet-based teaching, which can significantly improve the connectivity and communication efficiency between students and teachers. This model contributes positively to better learning effect and thus has attracted the attention of many scholars.

On April, 2001, the Ministry of Education initiated a national online course project to achieve the goal of university talent cultivation in the new century, and urged all universities to build online courses accordingly in line with their own characteristics and major planning locally. These courses cover all majors and students from various educational backgrounds, satisfying the demands of students from all majors and educational backgrounds to the most extent. In 2003, the Ministry of Education, by cooperation with relevant network service providers, formulated the technical specification and principle of online course setting and setting plans as a guide to universities [1].

China has now built 68 online education schools and develop many online education institutions for company staff and people in the society to meet their education demands. Also, many enterprises and private education institutions participated to build many practical online courses [2]. In 2001, the Ministry of Education established Modern Distance Education Research Institute which later put forward a large number of online courses for middle school, high school and university students. Some universities, based on their students' demand for better education, built some 
targeted online courses. For example, Zhejiang University set 57 online courses while Tsinghua University set 50 for students from 6 majors.

A few years later, online courses have witnessed great progress. To classify these courses, the Ministry of Education initiated an activity to select excellent online courses. In 2007, as many as 2457 courses covering wide fields such as science and technology, humanities and social science participated and 49 stood out [3]. The quality of network courses plays a decisive role in the effect of teaching and thus we need to prepare enough software and hardware to guarantee the quality of these courses. For this, many colleges and universities establish many types of network course resource database in various ways, like digital libraries, network course database, which provide strong support for the efficient utilization of resources and the hardware and software guarantee of network education. At present, network course education is at the stage of rapid development and many scholars have conducted researches from different perspectives. However, the majority of these researches focus on how to build good network course resources and how to better play the role of teaching effect [4].

\section{Comparison among Network Course, Traditional Classroom Teaching and Network Courseware}

1. Compared with traditional classroom teaching, network course education has many advantages, which is embodied in the aspect of teaching material and information transfer mode. Paper-printing material is mainly used in traditional education and corresponding information is transferred by words and images. Electronic teaching material is used in network education and information can be transferred by diverse medium forms like images, audio, video and animation, which is more intuitive and leaves deeper impression on learners [5]. Meanwhile, network education can describe teaching content from multiple layers and perspectives, making complex knowledge more concrete and visualized, which plays a very important role in arousing the learning interest and enthusiasm of students. In addition, under this model, learners can master the knowledge more systematically and improve their learning effect. It is convenient for learners to use various teaching resource databases and information database based on their own learning needs and communicate with other learners over the network. Therefore, this teaching mode can better satisfy the learning needs of learners with various identities and education background on the whole.

2. Independence of Learning. There is no teacher to supervise learning in network education, and thus learners must rely on independent learning. They can sail in the ocean of knowledge at will and choose rich knowledge resources based on their learning interests and needs. They can also have the freedom to choose learning tools and reference material, thus having high flexibility [6].

3. Individualization of Teaching. Traditional education is limited by time and teaching resources and thus a large proportion of learners do not have access to high level of education. However, these limitations are eliminated by network educa- 
tion. Learners can search and utilize network education resources through the network freely and they car not limited by time or location. In addition, under this model, learners have high learning autonomy. They can choose suitable learning methods and correspond to their cognitive rules and experience flexibly, thus better satisfying personalized needs.

4. Cooperation of Activities. Network education is highly interactive and it is very convenient for learners to communicate by email, forum or QQ group. They are hardly restricted by identity, which makes it possible for teachers to know the learning status and answer the questions of learners in time by communication. Under this learning model, the initiative and creativity of learners have been significantly improved and the learning effect is obviously better than traditional teaching model.

\section{Investigation and Analysis of Learning Situation of Public English Network Courses of University Students}

\subsection{Experimental Subject}

This paper conducts corresponding questionnaire research to study the learning effect of English network courses and selects 287 students of five universities in five states in Yunnan Province. Altogether 287 questionnaires are distributed and 276 questionnaires are recovered. The number of invalid questionnaires is 33 and the effective rate is $91.6 \%$. In terms of valid questionnaires, 34 students come from Wenshan University and 56 students come from Yunnan University, covering a wide range of majors, like computer, physical science, economic management, preschool education and English. The respondents are mainly distributed in three grades while the overwhelming majority is freshman, the number of which is 114 . The number of students of liberal arts and science is 151 and 102 respectively while the number of male and female students is 122 and 131 respectively.

\subsection{Content Design of Questionnaire}

This questionnaire includes five subscales, which are basic information of students (age, gender and major); learner elements (learning purpose, attitude, method and experience); teacher elements (corresponding teaching attainment); course elements (corresponding design of course interface, content and major); environment elements (learning atmosphere, corresponding supporting conditions and environment). Experiments are conducted before the design of questionnaires and appropriate modification is carried out based on the results. After that, formal questionnaire is determined. Altogether 26 questions are included in this questionnaire.

This questionnaire conducts statistical analysis of quality of learners themselves, teachers, course design and learning environment and the specific conditions and score characteristics are as follow: 
1. Learner Factor. The concrete content of this factor is shown in Figure 1.

2. Teacher Factor. The concrete content of this factor is shown in Figure 2.

3. Public English Network Course Factor. The concrete content of this factor is shown in Figure 3.

4. Learning Environment Factor. The concrete content of this factor is shown in Figure 4.

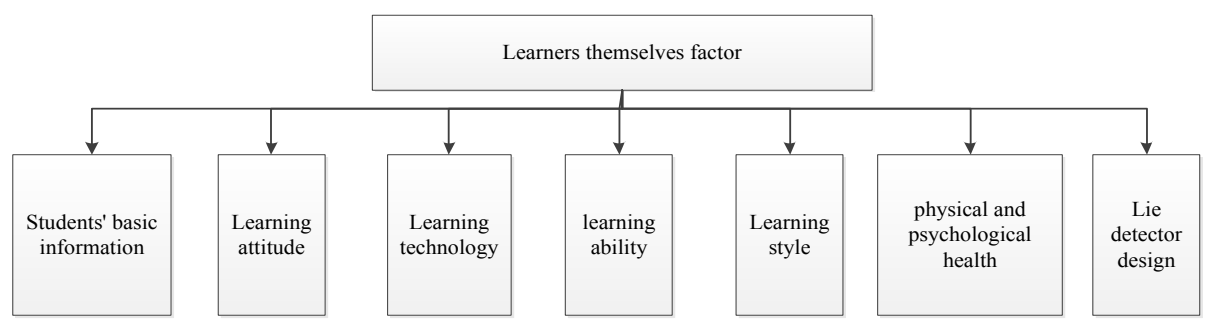

Fig. 1. Leaner Factor

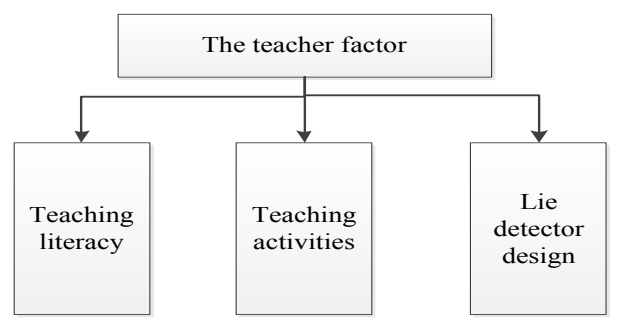

Fig. 2. Teacher Factor

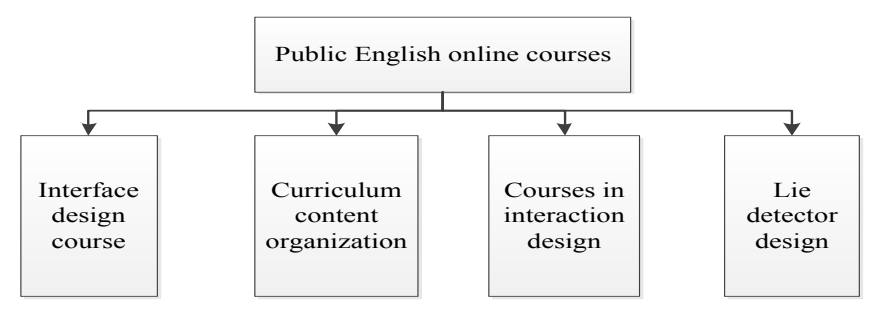

Fig. 3. Public English Network Course Factor

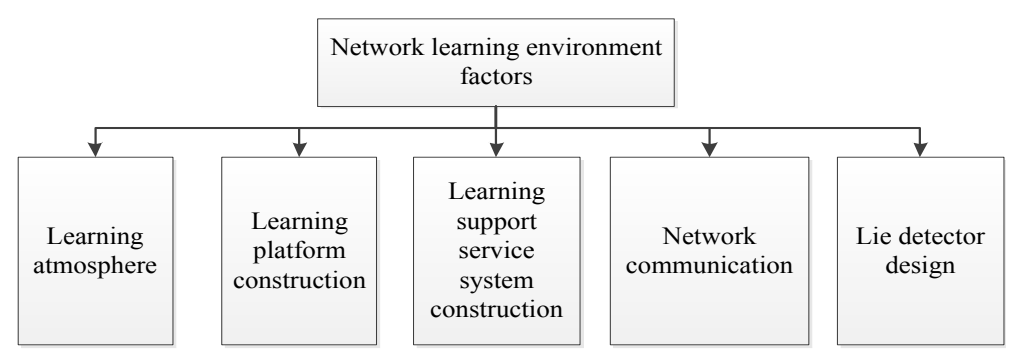

Fig. 4. Public English Network Learning Environment Factor 


\subsection{Deep Analysis of Public English Network Course Learning}

Gender Difference of University Students in Public English Network Learning. This paper selects the gender of university students as independent variable when studying and conducts independent sample test on this factor. The results indicate that there are gender difference of university students in learning public English network courses and the specific conditions are as follow.

Difference of their own factors of university students of different genders. The results of independent sample test on their own factors are shown in Table 1. We can see from the analysis of this Table that significant difference can be observed in learning attitude and learning technology of university students with different gender. The value of the latter factor is 2.56 and 2.37 for male and female students respectively and $\mathrm{P}=0.029$, showing obvious statistical discrepancy. This result shows that the level of information technology application of male students is higher than that of female students. However, we can see from the value of learning attitude factor that the learning attitude of male students is worse than that of female students. The value is 2.62 and 2.76 respectively, but the difference is not evident.

We can also see from the analysis of this Table that minor difference can be observed in the learning motivation and learning style of male and female students. The value of female students is slightly higher while the average value of learning technology of male students is higher. However, these differences are not statistical discrepancy. The value of physical and mental health of male and female students is roughly the same.

Difference of Public English network learning environment factor of university students of different genders. This paper selects gender as independent variable and conducts independence test on corresponding course factor, the results of which is shown in Table 2. We can see from the analysis of this Table that the differences in attitudes towards course learning platform of male and female students is obvious, corresponding value being 2.30 and 2.05 , which is statistical discrepancy. We can make the judgment that male students have a deeper understanding of course learning platform while no difference can be observed in other factors. The results also indicate that the value of learning atmosphere and support service system is roughly the same between male and female students and they all hold that the network communication in their universities has reached a high level.

Major Difference of University Students in Public English Network Course Learning. This paper selects the major of experimental objects as independent variable and conducts independent sample test on this factor. The results are shown in Table 3. We can see from the analysis of this Table that the difference of learning ability factor of arts and science students is obvious and the value is 2.28 and 2.51 respectively, which is significant statistical discrepancy. This result is consistent with the inferred result. Science students have more access to computers and they are more accustomed to learning English over the network. Arts students generally select traditional way to study. There is no statistical discrepancy in the average value and $\mathrm{P}$ value of other factors for arts and science students. 
Paper-Investigation and Research on the English Learning Status of University Students Based on Com..

Table 1. Difference of Their Own Factors of University Students of Different Genders

\begin{tabular}{|l|c|c|c|c|c|c|}
\hline \multirow{2}{*}{\multicolumn{1}{|c|}{ Their own factors }} & \multicolumn{2}{|c|}{ Male } & \multicolumn{2}{c|}{ Female } & \multirow{2}{*}{ T } & \multirow{2}{*}{ P } \\
\cline { 2 - 6 } & Average & $\begin{array}{c}\text { Standard } \\
\text { deviation }\end{array}$ & Average & $\begin{array}{c}\text { Standard } \\
\text { deviation }\end{array}$ & & \\
\hline Learning motivation & 2.95 & 1.021 & 2.96 & 1.055 & 1.102 & 0.362 \\
\hline Learning attitude & 2.63 & 1.036 & 2.74 & 1.017 & 2.845 & 0.014 \\
\hline Learning technology & 2.47 & 1.024 & 2.41 & 1.056 & 1.472 & 0.025 \\
\hline Learning ability & 2.33 & 0.859 & 2.36 & 0.952 & 0.965 & 0.624 \\
\hline Learning style & 2.30 & 0.865 & 2.41 & 0.960 & 0.945 & 0.265 \\
\hline The physical and mental health & 2.25 & 1.052 & 2.45 & 1.102 & 1.104 & 0.541 \\
\hline
\end{tabular}

Table 2. Difference of Public English Network Course Learning Environment Factor of Different Genders

\begin{tabular}{|c|c|c|c|c|c|c|}
\hline \multirow[b]{2}{*}{ Network learning factor } & \multicolumn{2}{|c|}{ Male } & \multicolumn{2}{|c|}{ Female } & \multirow[b]{2}{*}{$\mathbf{T}$} & \multirow[b]{2}{*}{$\mathbf{P}$} \\
\hline & Average & $\begin{array}{l}\text { Standard } \\
\text { deviation }\end{array}$ & Average & $\begin{array}{l}\text { Standard } \\
\text { deviation }\end{array}$ & & \\
\hline Learning atmosphere & 2.23 & 0.69 & 2.15 & 0.74 & 1.09 & 0.78 \\
\hline Course learning platform & 2.23 & 0.85 & 2.05 & 0.75 & 1.52 & 0.045 \\
\hline The support service system & 2.14 & 0.84 & 2.12 & 0.98 & 0.74 & 0.36 \\
\hline Network communication & 3.21 & 0.96 & 3.39 & 1.02 & 0.18 & 0.85 \\
\hline
\end{tabular}

Table 3. Major Difference of University Students in Public English Network Course Learning

\begin{tabular}{|c|c|c|c|c|c|c|}
\hline \multirow[b]{2}{*}{ Their own factors } & \multicolumn{2}{|c|}{ liberal arts } & \multicolumn{2}{|c|}{ Science } & \multirow[b]{2}{*}{$\mathbf{T}$} & \multirow[b]{2}{*}{$\mathbf{P}$} \\
\hline & Average & $\begin{array}{l}\text { Standard } \\
\text { deviation }\end{array}$ & Average & $\begin{array}{l}\text { Standard } \\
\text { deviation }\end{array}$ & & \\
\hline Learning motivation & 2.95 & 1.021 & 2.96 & 1.055 & 1.102 & 0.362 \\
\hline Learning attitude & 2.63 & 1.036 & 2.74 & 1.017 & 2.845 & 0.014 \\
\hline Learning technology & 2.47 & 1.024 & 2.41 & 1.056 & 1.472 & 0.025 \\
\hline Learning ability & 2.33 & 0.859 & 2.36 & 0.952 & 0.965 & 0.624 \\
\hline Learning style & 2.30 & 0.865 & 2.41 & 0.960 & 0.945 & 0.265 \\
\hline $\begin{array}{l}\text { The physical and } \\
\text { mental health }\end{array}$ & 2.25 & 1.052 & 2.45 & 1.102 & 1.104 & 0.541 \\
\hline
\end{tabular}

\section{Countermeasure Discussion of Public English Network Course Learning}

\subsection{Process Analysis of Public English Network Course Learning Activities}

Concrete analysis of English network learning activities of universities is conducted in the following part. This type of activity is the sum of related behaviors to complete a specific learning target. In terms of public English network learning of universities, the corresponding content mainly includes task and topic of activities, process, supervision and evaluation rules. The learning activities of network courses have 
unique performance, which is significantly different from ordinary teaching. In learning activities of network courses, learners are the subject of learning and they have strong independence and autonomy. The learning activities of network courses mainly include:

1. Design corresponding network platform on the basis of these activities.

2. Provide learners with support of various learning tools.

3. Provide learners with rich learning resources and materials for flexible application.

4. Provide good support for the interaction between teachers and students and provide certain communication environment.

5. Arrange corresponding activity tasks considering their individual differences.

6. Supervise their learning behaviors in various ways.

7. Evaluate learning effect in through diversified methods.

Public English plays a very important role in university education. University students can study over the network or in traditional classrooms. From the practical situation of English teaching in universities in Yunnan Province, it is classroom teaching that holds larger proportion. Network courses play a supporting role in this process. Many students choose to do exercise or broaden their knowledge after class via network. Moreover, teachers and students can communicate or interact with each other on network education platform. Teachers can take advantage of the backstage to check their learning status and answer the questions left by students.

\subsection{Countermeasure Discussion of Improving Public English Network Course Learning}

Transforming learning beliefs and establish good network course learning concept. Studies have found that many students still retain their original learning habit and style after entering the university. They still acquire knowledge by classroom learning and learn by rote without utilizing network resources [8-9]. In this way, they cannot adapt to the need of public English learning under this network situation and are out of step with the times. Therefore, university students need to transform traditional learning beliefs and actively learn English through public English network course. They need to automatically select and process external information flexibly and establish and perfect their knowledge system based on their own learning status and characteristics. After that, they can achieve benign development on this basis. In the mode of network course education, teachers hardly participate in teaching and the role of teachers is mainly supervision and coaching. Therefore, students are highly independent. This requires students to have self-controlling ability and appropriate guidance form teachers, which can help them to gradually establish this learning habit.

Improving time management ability of public English network course learning. At present, the learning time arrangement of most universities students is not reasonable and they often face the conflict between network course and traditional course learning. Moreover, they mainly focus on traditional course learning, ignoring the role of network course [10]. We can see from the statistical results of the ques- 
tionnaire that many students regard tight time as the major reason influencing the learning effect of public English network course. A significant proportion of university students do not have enough time to learn public English network course, which requires them to allocate learning time rationally and formulate scientific learning plans. They need learn network course strictly following the plan. In addition, teachers can help them to formulate learning plans and enhance their time management ability through training, thus laying a solid foundation for ensuring learning effect.

Multi-subject of public English network course learning resource development. Universities should develop public English network course based on the actual English learning situation of students and establish diversified development main bodies. Universities need to develop English course resources more in line with their learning characteristics and learning needs according to the feedback of students. Meanwhile, teachers should provide reasonable guidance for students to help them utilize information resources on the Internet and reduce their learning dependence.

Establish sound public English network course learning interaction module. Teachers need to answer the questions of students on the network course interaction platform and provide appropriate guidance for students. The results of the investigation indicate that $70 \%$ of students think this type of network course platform lacks rich interaction function and teachers cannot answer their questions in time. Some students also think that corresponding interaction modules need to be improved. Teachers can set some student forum moderator and they can organize students to raise questions, exchange learning status and share some exercise materials and answers. The communication channel of teachers and students should be broadened and email and forum should be added to answer the learning questions of students, providing them with better guidance. In addition, help column should also be set up. Moderators can collect the representative and typical questions of students and then teachers can answer these questions at the same time, which improves interaction efficiency and saves educational resources.

\section{Conclusion}

This paper studies the learning situation of public English network course of university students and selects five universities in Yunnan Province to conduct questionnaire. And then, this paper collects the statistical results and conduct factor analysis on this basis. Finally, this paper determines the factors influencing the learning effect of public English network course of university students and gives some improvement suggestions in expectation of improving English learning effect.

\section{References}

[1] Tsui, A.B.M., Wu, K., Sengupta, S. (1996). Enhancing teacher development through telenex, a computer network for English language teachers. System, 24: 461-476. https://doi.org/10.1016/S0346-251X(96)00042-5 
Paper-Investigation and Research on the English Learning Status of University Students Based on Com...

[2] Higashi, T., Oda, T., Yamagiea, A. (1983). An interim report on development of multimedia educational systems - English teaching using personal computer. British Medical Journal, 287: 337-339.

[3] Lan, Y.J., Sung, Y.T., Chang, K.E. (2009). Let us read together: development and evaluation of a computer-assisted reciprocal early english reading system. Computers \& Education, 53: 1188-1198. https://doi.org/10.1016/j.compedu.2009.06.002

[4] Xiong, L., Ling, Z. (2010). On building computer-based college English teaching quality assurance system. International Conference on Computer Design and Applications, 2: 284288.

[5] Wang, Y. (2010). English interactive teaching model which based upon Internet of Things. International Conference on Computer Application and System Modeling, 13: 587- 590.

[6] Dung, N.V., Sulaiman, S., Hassan, M.F. (2012). Towards the development of an online adaptive system framework for English learning using perturbation learner model. International Conference on Computer \& Information Science, 1.1: 512-516.

[7] Meyer, B. (2009). Learning English through Serious Games - Reflections on Teacher and Learner Performance. International Conference on E-Learning and Games: Learning by Playing. Game-Based Education System Design and Development, 3: 293-293.

[8] Sun, C.Y. Chang, K.Y. (2016). Design and development of a location-based mobile learning system to facilitate english learning. Universal Access in the Information Society, 15: 345-357. https://doi.org/10.1007/s10209-014-0392-x

[9] Vakil, Z., Khadivi, S. (2013). Development and enhancement of an interactive computerassisted translation system for english to persian (written in persian language). Journal of Hydraulic Engineering, 138: 897-901.

[10] Hofmann, J.N., Checkoway, H., Borges, O., Servin, F., Fenske, R.A., Keifer, M.C., Development of a computer-based survey instrument for organophosphate and n-methylcarbamate exposure assessment among agricultural pesticide handlers. Annals of Occupational Hygiene, 54: 640-650.

\section{Author}

Yanli Guo: (1980.5), (Weifang, Shandong, China). Current position, grades: the lecturer of English specialty, Weifang University of Science and Technology, Shandong, China. Scientific interest: his research interest fields include subject teaching and English education. Publications: more than 5 papers published. Experience: he has English teaching experience of 12 years, has completed three scientific research projects.

Article submitted 15 May 2017. Published as resubmitted by the author 17 June 2017. 